\title{
FBX011 Gene
}

National Cancer Institute

\section{Source}

National Cancer Institute. FBXO11 Gene. NCI Thesaurus. Code C101104.

This gene plays a role in the recognition of proteins to be ubiquitinylated. 